\title{
EVALUASI SIKAP DAN PERILAKU SISWA TERHADAP LINGKUNGAN HIDUP DAN PEMBANGUNAN BERWAWASAN LINGKUNGAN DI MADRASAH
}

\author{
Neni Wahyuningtyas ${ }^{1}$
}

\begin{abstract}
Environmental education is one effort to realize environmental sustainability for present until future. Explicitly, it shows that human effort to save environmental must be done continuously, relay from one generation to the next generation. In fact, there is problem about behavior and attitude of student class XI at MA Nurul Ulum Munjungan Trenggalek towards environmental sustainability. Most of student have less concern towards environmental sustainability, for examples throwing the rubbish everywhere, letting classroom dirty, plant that are not caring well, and excessive use of water. In order to describe the behavior and attitude of students towards environmental and development based on environmental, evaluation about behavior and attitude of student is needed to be done actually and systematically.
\end{abstract}

Keywords: Evaluation, behavior, environmental behavior.

\section{A. Pendahuluan}

Pendidikan lingkungan hidup merupakan bentuk dalam upaya mewujudkan kelestarian lingkungan untuk masa sekarang hingga masa yang akan datang. Secara eksplisit menunjukkan bahwa perjuangan manusia untuk menyelamatkan lingkungan hidup harus dilakukan secara berkesinambungan, dengan jaminan estafet antar generasi yang dapat dipertanggungjawabkan.

Kharakteristik pendidikan lingkungan hidup adalah pendidikan yang lebih banyak mengantipasi keadaan yang akan terjadi di masa yang akan datang. Tujuan pendidikan lingkungan hidup adalah untuk membekali generasi masa kini dengan pengetahuan lingkungan hidup, sikap dan kemampuan lain yang sesuai untuk menghindari krisiskrisis yang mungkin terjadi, memecahkan masalah lingkungan yang sedang dihadapi dan meralat ketimpangan-ketimpangan lingkungan

1 Dosen Fakultas Ilmu Tarbiyah Dan Keguruan Universitas Islam Negeri Maulana Malik Ibrahim Malang Jl. Gajayana No. 50 Malang 65144 
berpedoman pada baku mutu lingkungan yang sudah diundangkan.

Penanaman pondasi pendidikan lingkungan sejak dini menjadi solusi utama yang harus dilakukan agar generasi muda memiliki bekal pemahaman tentang lingkungan hidup yang kokoh. Pendidikan lingkungan hidup diharapkan mampu menjembatani dan mendidik manusia agar bersikap dan berperilaku bijak. Dengan demikan sangatlah strategis pembekalan pengetahuan dasar tentang lingkungan hidup melalui anak-anak secara terprogram dan berkelanjutan hingga pada saatnya akan tercipta insan-insan pribadi bangsa yang utuh.

Informasi yang diperoleh seseorang mengenai suatu objek berpengaruh terhadap pembentukan sikap mengenai objek tersebut. Semakin jelas informasi mengenai suatu objek diperoleh seseorang, semakin besar kemungkinan terbentuknya sikap terhadap objek itu.

Pelestarian lingkungan tidak terlepas dari sikap dan perilaku seseorang. Oleh karena itu untuk menghindari terjadinya perusakan terhadap lingkungan diperlukan sikap dan perilaku positif terhadap lingkungan sehingga tercipta keseimbangan lingkungan yang dapat menunjang pembangunan. Sikap dan perilaku terhadap pelestarian lingkungan sangat penting bagi setiap individu. Sikap tersebut akan berbeda antar individu, karena banyak sekali faktor yang ikut mempengaruhi sikap individu terhadap lingkungan antara lain adalah jenis kelamin, umur, pendidikan, status sosial, taraf penguasaan terhadap obyek tertentu dan orientasi pada norma sosial (Margono,1995:3). Faktor-faktor tersebut mempengaruhi proses sosialisasi yang berbeda sehingga menimbulkan ciri psikologis yang berbeda-beda dan akhirnya akan terbentuk sikap yang khas terhadap berbagai hal termasuk masalah pelestarian lingkungan. Sikap yang khas dari seseorang ini akan mempengaruhi kecenderungan untuk berperilaku atau bertindak terhadap suatu obyek.

Demi terwujudnya pelestarian lingkungan hidup, pendidikan sangat memegang peranan penting dalam masyarakat karena pendidikan menanam pengetahuan, memberi ketrampilan yang diperlukan dan menolong dalam pembentukan sikap tertentu. Melalui pendidikan lingkungan hidup yang dilakukan sejak dini merupakan langkah strategi dalam upaya mengubah sikap dan perilaku para peserta didik agar lebih peduli terhadap pentingnya lingkungan hidup serta memiliki ketrampilan untuk mencegah dan menanggulangi terjadinya pencemaran maupun 
perusakan lingkungan. Oleh karena itu, pada sektor pendidikan perlu disertakan secara aktif terutama dalam membenahi sikap dan perilaku siswa dari sikap perusak lingkungan menjadi ramah lingkungan atau insan pecinta lingkungan. Di satu pihak sikap bertanggung jawab siswa terhadap lingkungan merupakan salah satu tujuan dari pendidikan, karena sikap tersebut harus terbentuk demi kesejahteraan manusia, akan tetapi di lain pihak kurang memperhatikan evaluasi terhadap pencapaian siswa pada aspek sikap (Supardi, 1994:5).

Kepedulian terhadap lingkungan merupakan peran dari setiap orang dan dituangkan dalam Undang-Undang No. 23 tahun 1997 pasal 5 ayat 3 tentang ketentuan pokok pengelolaan lingkungan hidup, yang isinya adalah "setiap orang mempunyai hak dan peran serta dalam pengelolaan lingkungan hidup" (Erawati, 2000,9). Dengan demikian, setiap orang bertanggung jawab terhadap pelestarian lingkungannya. Pendidikan dipandang tepat dan strategis dalam mempersiapkan pendidikan lingkungan hidup bagi generasi mendatang. Pendidikan lingkungan hidup dilakukan melalui pendidikan formal maupun non formal. Pendidikan formal dilakukan dari tingkat Sekolah dasar sampai dengan perguruan tinggi atau melalui pendekatan integratif. Salah satu materi yang berkaitan dengan lingkungan hidup pada pelajaran geografi adalah pemberian materi lingkungan hidup dan pembangunan berwawasan lingkungan yang telah diajarkan kepada siswa kelas XI MA Nurul Ulum Munjungan Trenggalek, sehingga dengan materi yang diajarkan tersebut diharapkan dapat menumbuhkan sikap dan perilaku yang positif terhadap pelestarian lingkungan hidup pada siswa.

Siswa MA Nurul Ulum Munjungan Trenggalek merupakan salah satu generasi penerus yang mempunyai hak dan kewajiban yang sama untuk memelihara kelestarian lingkungan hidup. Dari hasil observasi di lapangan diketahui bahwa terdapat masalah mengenai sikap dan perilaku siswa terhadap pelestarian lingkungan. Dimana diketahui jika sebagian besar siswa kurang memiliki kepedulian terhadap lingkungan, misalnya membuang sampah di sembarang tempat, kebersihan kelas yang kurang terjaga, tidak terawatnya tanaman di taman sekolah dan penggunaan air yang berlebihan.

Paparan di atas membawa peneliti pada masalah penelitian yaitu: bagaimanakah sikap siswa terhadap lingkungan hidup dan pembangunan 
Neni Wahyuningtyas - Evaluasi Sikap dan Perilaku Siswa...

berwawasan lingkungan siswa kelas XI MA Nurul Ulum Munjungan Trenggalek pada pelestarian lingkungan dan bagaimanakah perilaku siswa terhadap lingkungan hidup dan pembangunan berwawasan lingkungan siswa kelas XI MA Nurul Ulum Munjungan Trenggalek pada pelestarian lingkungan. Adapun tujuan dari penelitian ini adalah: untuk mengetahui sikap dan perilaku siswa terhadap lingkungan hidup dan pembangunan berwawasan lingkungan siswa kelas XI MA Nurul Ulum Munjungan Trenggalek pada pelestarian lingkungan.

\section{B. METODE}

Penelitian ini merupakan explainatory research. Penelitian ini apabila ditinjau dari jenis variabelnya, maka penelitian ini berbentuk penelitian deskriptif yang di dalamnya mendeskripsikan sikap dan perilaku siswa terhadap lingkungan hidup dan pembangunan berwawasan lingkungan. Penelitian deskriptif yaitu penelitian yang bertujuan untuk membuat pencandraan secara aktual dan sistematis tentang sifat-sifat objek (individu, masyarakat, lembaga dan lain-lain) (Arikunto; 2002:9). Penelitian ini berbentuk deskriptif dengan menggunakan metode survey.

Sampel dalam penelitian ini menggunakan sampel kelas, karena keseluruhan kelas di MA Nurul Ulum Munjungan Trenggalek bersifat homogen dan diambil dua kelas sebagai sampel dengan menggunakan teknik random sampling yaitu dengan cara diundi antara kelas XI IPS 1, XI IPS 2, dan XI IPS 3. Sample yang didapat dari cara undian ini adalah kelas XI IPS 1 dan XI IPS 2 dan diambil 74 siswa sebagai sampel.

Instrumen penelitian merupakan alat bantu dalam pengumpulan data (Arikunto,2002:126). Dalam penelitian ini yang dipakai sebagai instrumennya adalah angket yang digunakan untuk mengukur sikap dan perilaku siswa terhadap pelestarian lingkungan. Dari hasil jawaban angket responden, masing-masing akan diberikan skor. Jumlah skor responden ditentukan oleh banyaknya skor responden yang menjawab sesuai dengan sikap dan perilakunya terhadap pelestarian lingkungan.

Untuk memperoleh penjelasan mengenai sikap dan perilaku siswa terhadap lingkungan hidup dan pembangunan berwawasan lingkungan digunakan teknik analisa persentase. Adapun rumusnya sepagai herikut: 


\section{HASIL PENELITIAN}

\section{1) Sikap Siswa Terhadap Pelestarian Lingkungan}

Variabel sikap siswa diukur dengan 23 item pertanyaan. Hasil dari pengukuran data tersebut disajikan dalam table 1.1 sebagai berikut:

Tabel 1.1 Distribusi Frekuensi Sikap terhadap pelestarian lingkungan

\begin{tabular}{ccccc}
\hline No & Interval kelas & Kategori & Frekuensi Absolut & $\begin{array}{c}\text { Frekuensi } \\
\text { Relatif }\end{array}$ \\
\hline 1 & $60-69$ & Kurang positif & 48 & 65 \\
2 & $70-79$ & Cukup positif & 25 & 34 \\
3 & $80-89$ & Positif & 1 & 1 \\
4 & $90-99$ & Sangat Positif & 0 & 0 \\
\hline
\end{tabular}

Berdasarkan tabel 1.1 dapat diketahui siswa yang mempunyai sikap kurang positif terhadap pelestarian lingkungan sebanyak 48 siswa $(65 \%)$, siswa yang mempunyai sikap cukup positif terhadap pelestarian lingkungan sebanyak 25 siswa (34\%), siswa yang mempunyai sikap positif terhadap pelestarian lingkungan sebanyak 1 siswa (1\%), sedangkan siswa yang mempunyai sikap sangat positif terhadap pelestarian lingkungan sebanyak 0 siswa $(0 \%)$. Dengan demikian dapat dikatakan bahwa sebagian besar siswa belum mempunyai sikap yang positif terhadap pelestarian lingkungan hidup.

\section{2) Perilaku Siswa Terhadap Pelestarian Lingkungan}

Variabel perilaku siswa diukur dengan 7 item pertanyaan. Hasil dari perhitungan data disajikan dalam tabel 1.2 sebagai berikut :

Tabel 1.2 Distribusi Frekuensi Perilaku terhadap pelestarian lingkungan

\begin{tabular}{lllll}
\hline No & Interval kelas & Kategori & $\begin{array}{l}\text { Frekuensi } \\
\text { Absolut }\end{array}$ & $\begin{array}{l}\text { Frekuensi } \\
\text { Relatif }\end{array}$ \\
\hline 1 & $19-22$ & Kurang positif & 40 & 54 \\
2 & $23-26$ & Cukup positif & 33 & 45 \\
3 & $27-30$ & Positif & 1 & 1 \\
4 & $31-34$ & Sangat Positif & 0 & 0 \\
\hline
\end{tabular}

Berdasarkan tabel 1.2 dapat diketahui siswa yang mempunyai perilaku kurang positif terhadap pelestarian lingkungan sebanyak 40 
siswa (54\%), siswa yang mempunyai perilaku cukup positif terhadap pelestarian lingkungan sebanyak 33 siswa (45\%), siswa yang mempunyai perilaku positif terhadap pelestarian lingkungan sebanyak 1 siswa (1\%), sedangkan siswa yang mempunyai perilaku sangat positif terhadap pelestarian lingkungan sebanyak 0 siswa $(0 \%)$. Dengan demikian dapat dikatakan bahwa sebagian besar siswa beum mempunyai perilaku yang positif terhadap pelestarian lingkungan hidup.

\section{PEMBAHASAN}

1. Sikap dan Perilaku Siswa Terhadap Lingkungan Hidup Dan Pembangunan Berwawasan Lingkungan Pada Pelestarian Lingkungan

Azwar dalam Sarwono (1997:13) mengatakan bahwa interaksi antara suatu lingkungan dengan sikap, dengan berbagai faktor di dalam dan di luar diri individu akan membentuk suatu proses kompleks yang akhirnya menentukan bentuk perilaku seseorang. Pengetahuan tentang lingkungan hidup dan pembangunan berwawasan lingkungan dapat mempengaruhi perilaku seseorang terhadap pelestarian lingkungan. Dengan memiliki kesadaran dan keyakinan yang kuat maka manusia akan cenderung untuk berperilaku sesuai dengan apa yang dipahami dan diyakininya, termasuk dalam hal menguasai materi lingkungan hidup dan pembangunan berwawasan lingkungan. Dengan memiliki pengetahuan yang luas, maka siswa akan cenderung untuk berperilaku yang positif terhadap lingkungannya.

Dari hasil penelitian ini membuktikan bahwa sikap dan perilaku siswa terhadap lingkungan hidup dan pembangunan berwawasan lingkungan, siswa kelas XI IPS 1 dan IPS 2 MA Nurul Ulum Munjungan Trenggalek kurang positif. Artinya siswa-siswi pada kelas tersebut masih kurang peduli terhadap lingkungan dan pembangunan berwawasan lingkungan. Adapun faktor-faktor yang mempengaruhi yaitu adanya sikap acuh tak acuh terhadap lingkungan dan kurangnya perhatian, pemahaman siswa terhadap materi yang diberikan oleh guru terutama materi tentang lingkungan hidup serta pembangunan berwawasan lingkungan.

Sebenarnya upaya untuk penumbuhan sikap dan perilaku yang positif terhadap lingkungan hidup dapat ditempuh melalui jalur pendidikan. Tetapi karena adanya faktor-faktor tersebut di atas 
menyebabkan upaya tersebut kurang terlaksana dengan baik.

Penumbuhan perilaku yang positif terhadap lingkungan dapat diperkenalkan atau disosialisasikan oleh pihak sekolah maupun terkait kepada siswa dengan berbagai cara. Perilaku yang positif terhadap lingkungan dapat diaplikasikan melalui keikutsertaan dan partisipasi siswa dalam menjaga dan melestarikan lingkungan sekolah, membuang sampah pada tempatnya, mengadakan kerja bakti dan mengikuti kegiatan ekstrakulikuler yang berkaitan dengan lingkungan hidup. Dengan demikian menjadikan siswa secara aktif ikut melestarikan lingkungan sekitarnya.

Selain itu pihak sekolah bersama siswa secara aktif saling menjaga lingkungan dengan cara mengadakan kerjabakti tiap minggu, mengadakan kegiatan yang berkaitan dengan masalah pelestarian lingkungan hidup. Kegiatan pelestarian lingkungan hidup ini dapat dilakukan seperti mengadakan kegiatan penanaman pohon disekolah, merawat lingkungan sekolah, sehingga siswa dapat menumbuhkan tindakan positif tersebut sesuai dengan pengetahuan ilmu yang telah diperoleh.

Berdasarkan penelitan ini sebagian besar siswa belum dapat melaksanakan atau menjaga lingkungan dengan baik. Hal ini dapat dibuktikan dengan lingkungan sekitar yang masih kurang terawatt. Berarti dalam penyampaian materi lingkungan hidup dan pembangunan berwawasan lingkungan kurang dipahami oleh siswa. Selain itu dalam penerimaan materi ini, siswa kurang siap dimungkinkan karena kurang adanya minat siswa dalam pelajaran geografi terutama dalam materi lingkungan hidup dan pembangunan berwawasan lingkungan.

\section{E. KESIMPULAN}

Sikap dan perilaku siswa XI IPS 1 dan IPS 2 MA Nurul Ulum Munjungan Trenggalek terhadap lingkungan hidup dan pembangunan berwawasan lingkungan ternyata kurang positif. Artinya siswa-siswi pada kelas tersebut masih kurang peduli terhadap lingkungan dan pembangunan berwawasan lingkungan. Adapun faktor-faktor yang mempengaruhi yaitu adanya sikap acuh tak acuh terhadap lingkungan dan kurangnya perhatian, pemahaman siswa terhadap materi yang diberikan oleh guru terutama materi tentang lingkungan hidup serta pembangunan berwawasan lingkungan. 
Neni Wahyuningtyas - Evaluasi Sikap dan Perilaku Siswa...

\section{DAFTAR PUSTAKA}

Arikunto, Suharsimi. 2002. Prosedur Penelitian. Jakarta: Rineka Cipta.

Erawati. 2000. Penurunan Materi SDA Dalam Pernumbuhan Sikap Dan Perilaku Siswa Kelas 2 SLTPN 22 Samarinda Pada Pengelolaan Lingkungan. Malang: Program Pendidikan Geografi Universitas Negeri Malang.

Mularsono. 1988. Pendidikan Lingkungan Sebagai Sarana Untuk Menunjang Pelestarian Hutan. Duta Rimba, 1998-1996/XIV.

Sarwono, dkk. 1997. Pengintegrasian Materi Pelestarian Lingkungan Hidup Ke Dalam Bidang Studi Biologi, Ekonomi, Dan Geografi di SMP Malang. Lemlit IKIP Malang.

Supardi, I. 1994. Lingkungan Hidup dan Kelestariannya. Bandung: Penerbit Alumni. 